Summer 2006

\title{
Laïcité in the United States or The Separation of Church and State in Pluralist Society
}

Elisabeth Zoller

University of Newcastle, Tyne, ezoller@indiana.edu

Follow this and additional works at: https://www.repository.law.indiana.edu/ijgls

Part of the Comparative and Foreign Law Commons, Constitutional Law Commons, and the International Law Commons

\section{Recommended Citation}

Zoller, Elisabeth (2006) "Laïcité in the United States or The Separation of Church and State in Pluralist Society," Indiana Journal of Global Legal Studies: Vol. 13 : Iss. 2 , Article 10.

Available at: https://www.repository.law.indiana.edu/ijgls/vol13/iss2/10

This Symposium is brought to you for free and open access by the Law School Journals at Digital Repository @ Maurer Law. It has been accepted for inclusion in Indiana Journal of Global Legal Studies by an authorized editor of Digital Repository @ Maurer Law. For more information, please contact rvaughan@indiana.edu.

\section{$\Psi$}

JEROME HALL LAW LIBRARY

INDIANA UNIVERSITY

Maurer School of Law
Bloomington 


\section{Laïcité in the United States or The Separation of Church and State in Pluralist Society}

\section{Cover Page Footnote}

American separation of church and state is much more exigent than French laïcité, in that it prohibits the state from helping one or all religions in any manner; either in making religious representatives accredited and recognized political interlocutors in political and social dialogue, in putting edifices at their disposition for religious practice, or in financing religious schools-all things that French public authority does to benefit certain religions present in the territory of the Republic. As a result, religions, churches, or sects in the United States are all on equal footing with the others; none is privileged. The downside of the situation is that freedom of religion is in no way helped or assisted as is often the case in France and in Europe more generally. La Conception Américaine de la Laïcité, Symposium. University of Paris II (Panthéon-Assas) - Paris, France, January 28, 2005 


\title{
Laicité in the United States or The Separation of Church and State in a Pluralist Society
}

\author{
Elisabeth Zoller*
}

\begin{abstract}
American separation of church and state is much more exigent than French laïcité, in that it prohibits the state from helping one or all religions in any manner; either in making religious representatives accredited and recognized political interlocutors in political and social dialogue, in putting edifices at their disposition for religious practice, or in financing religious schools-all things that French public authority does to benefit certain religions present in the territory of the Republic. As a result, religions, churches, or sects in the United States are all on equal footing with the others; none is privileged. The downside of the situation is that freedom of religion is in no way helped or assisted as is often the case in France and in Europe more generally.
\end{abstract}

\section{INTRODUCTION}

Laïcité is often presented as a "French exception," an apt designation, at least linguistically. The term cannot truly be translated into non-Romance languages. For the rest, as the Conseil d'Etat has wisely said, "[i]f it is an exception, it can only be relative." The important question is obviously not the word, but the idea it represents. What is it that hides behind the word "laïcite"? For lawyers, the answer is simple. In law, laïcité is always defined as the separation of church and state. When the First Article of France's 1958 Constitution defined France as a "secular Republic," it meant neither more nor less than that the

*Professor of Law, Université Paris II (Panthéon-Assas); Visiting Professor of Law (Indiana University School of Law-Bloomington). This article is a slightly modified version of a piece presented on January 28, 2005 at a symposium on "La Conception Américaine de la Laïcité" at the Université Paris II (Panthéon-Assas). It was published in French as Elisabeth Zoller, La laïcité aux Etats-Unis ou la separation des Eglises et de l'Etat dans la societe pluraliste, in LA CONCEPTION américaine de la laïcité [AMerican conception of Secularism] 3 (Elisabeth Zoller ed., 2005) [hereinafter LA conception]. My appreciation goes to Holly Hinckley Lesan and Leora Jane Baude for their assistance with this translation.

1. Un siècle de laḯcité [A Century of Secularism], 55 Etudes et documents du Conseil d'Etat [Studies and Documents of the Conseil d'Etat] 241, 245 (2004). 
French Republic is founded on the principle of separation of state and religion; it is no longer, as was the case in 1789 , based on the ecclesiastical foundation of the state. Laïcité excludes religion and religions of the state; it prohibits the state from collaborating or cooperating with one religion, either in directing its organization or its functioning, or in allowing its clerics to meddle in public affairs. ${ }^{2}$

Very few states are truly secular states. That is to say, few states not only refuse to legally recognize one, some, or all religions present in the territory (either in conferring rights upon them, or in imposing obligations upon them in the public sphere, notably in the public school sphere), but also compel religion to exist purely in the private sphere. Within the European Union, France is isolated as a secular Republic; ${ }^{3}$ outside of the European Union, the situation is no different. ${ }^{4}$

2. As Guy Haarscher explains, the secular state "pertains to all the laos (one of the words signifying 'people' in ancient Greek), and not to those who share a particular religious conception (or non-religious) of life" in "the neutrality, liberty and protection of minorities." Guy Haarscher, $L a$ Neutralité, L'intégrité et la Protection des Minorités [Neutrality, Integrity and the Protection of Minorities], in L'Etat au XXe Siècle [The State in the 20th Century] 249, 261 (Simone GoyardFabre ed., 2004).

3. For example, neither the United Kingdom nor Germany are secular states; the former because it recognizes the Anglican religion as the established religion (on the situation of the Anglican church, the church established in England, see Duncan Fairgrieve, L'État et l'Église au Royaume-Uni [The State and the Church in the United Kingdom], in UN SIÈCLE DE LAÏCITÉ [A CeNTURY OF SECULARISM], supra note 1, at 437-444), and the latter because, though it does not recognize an established religion, it organizes a regime of institutional cooperation with all sects. See Thierry Rambaud, Le Principe de Séparation des Cultes et de l'État en Droit Public Comparé: Analyse Comparative des Régimes Français et Allemand [The Principal of Separation of Religions and the State in Comparative Public Law: Comparative Analysis of the French and German Systems] (2004). Similarly, in Spain, article 16(3) of the Constitution of December 27, 1978, declares that "public authorities shall take the religious beliefs of Spanish society into account and shall in consequence maintain appropriate co-operation with the Catholic Church and the other confessions." Constrrución [C.E.] art. 16, § 3 (Spain). In Italy, the relationship of religious confessions with the state is "regulated by law, based on agreements with their representatives." Costituzione [Cost.] [Constitution] art. $8, \S 3$ (Italy).

4. Despite appearances, see Le Rapport de la Commission Stasi sur la Laïcité [Report of the Stasi Commission on Secularism], Le Monde (Paris), Dec. 12, 2003, at 17, 18, 24, II 1 1.2.3, 4.3.4.2 [hereinafter Stasi Report] (referring to the Québecois regime as a model of reasonable accomodation), Canada is not a secular state, in that its 1867 constitution formally recognizes the "[r]ight or [p]rivilege of the Protestant or Roman Catholic [m]inority of the Queen's [s]ubjects in relation to [e]ducation." Constitution Act, 1867, 30 \& 31 Vict. Ch. 3 (U.K.), as reprinted in R.S.C., No. 5 (Appendix 1985). 
Among Western states, ${ }^{5}$ the only state in company with the French Republic in the camp of truly secular states is the United States.

Like the French Republic, the "Great Republic" is secular." If the word laïcité does not figure in the political landscape, the federal Constitution of September 17,1787, and the Bill of Rights that accompanies it contain clauses which unmistakably signify its implied presence. These clauses can be read as a mirror of the French dispositions relative to laïcité. To Article VI, clause 3 of the Constitution, which declares "no religious Test shall ever be required as a Qualification to any Office or public Trust under the United States," article 6 of the Declaration of the Rights of Man and Citizen of 1789 responds, "All citizens, being equal in the eyes of the law, are equally eligible to all dignities and to all public positions and occupations, according to their abilities, and without distinction except that of their virtues and talents." ${ }^{8}$ To the first words of the First Amendment of the Bill of Rights, which enjoins Congress from making any law "respecting an establishment of religion," (Establishment Clause), article 2 of the Law of December 9, 1905, concerning the separation of church and state, responds, "the Republic ... recognizes no association of worship." And to the second phrase of the First Amendment, which enjoins Congress from making any

5. Secular states outside the West include Turkey (article 2 of the Constitution declares, "The Republic of Turkey is a democratic, secular and social state governed by the rule of law"; Article 24 prohibits the setring aside, even partially, the order of the State on religious precepts; article 68 expressly forbids political parties to attack or undermine secularism). See Gilles Lebreton, Lislam devant la Cour européenne des droits de l'homme [Islam before the European Court of Human Rights], 5 Revue du Droit Public [Public Law Review] 1493 (2002); Japan (article 20 of the 1946 constitution declares, "Freedom of religion is guaranteed to all." It also provides, "No person shall be compelled to take part in any religious acts, celebration, rite or practice." Article 89, which appears in the chapter relating to public finance, prohibits the appropriation of any public money or other property for the use, benefit or maintenance of any religious institution or association. See Yoïchi Higuchi, La réception du constitutionalisme dans les zones culturelle extra-occidentales: laïcité dans la pratique de la justice constitutionnelle japonaise [The Introduction of Constitutionalism in the Eastern Asian Worship Zones: Separation of Church and State in the Practice of Japanese Constitutional Justice], 16 ANNuAiRE INTERNaTIONAL de Justice CONSTiturionnelle [International Yearbook of International Justice] 490, 495 (2000).

6. See Camille Froidevaux-Metterie, Les Etats-Unis: Une République Laïque [The United States: A Secular Republic], in La Conception, supia note *, at 89.

7. U.S. ConsT. art. VI, §3.

8. The Declaration of the Rights of Man and of the Citizen art. Vi (Fr. 1789).

9. U.S. Const. amend. I. 
law "prohibiting the free exercise thereof," ticle of the Constitution of 1958 echoes, "[France] shall respect all beliefs."

The secular cultures of France and the United States share an explanation for this secularism: the same Enlightenment philosophy nourished their respective revolutions. France is the daughter of Jefferson, as the United States is the heir of Voltaire. The essential teaching of these philosophers on the relationship between church and state is that religion is a private affair and must remain such, and that religion cannot expect from the state anything other than perfect neutrality. Liberty of conscience, which is the first step toward religious liberty, is the first liberty and the founding rock of modern democracy, to the extent that the postulate of modern democracy is free will. Free will excludes all religious determinism, when it comes to taking care of civic affairs.

The separation between religion and politics is a fundamental criterion that distinguishes a modern democracy from an ancient one. Ancient democracy lived under the watchful eyes of the gods; religion determined everything. It dominated both public life (where nothing was decided without consulting the oracles) and private life (which was always determined by the tutelary deity of the lares). Everything was completely subject to the commands of the gods. The destiny of man did not belong to him, any more than the destiny of the polity; all was in the hands of the gods. As Benjamin Constant has said in speaking of ancient democracy, "Nothing was granted to individual independence, neither relating to opinions, nor industry, nor especially relating to religion. Freedom to worship, a freedom we consider as one of our most invaluable rights, would have appeared a crime and a sacrilege." 12 Modern democracy does not chase religion from civic life, but rather obligates it to be a personal affair, distinct and separate from public affairs. In this sense, modern democracy requires the separation of church and state because it must, in order to exist and achieve, drive religion out of the sphere reserved for politics in the city: that is to say, the public sphere. Democracy and the separation of church and state are indistinguishable in the realization that modern liberty is understood as "the capacity to emanci-

10. Id.

11. La Constitution [Const.] art. I (Fr.).

12. Of the liberty of the ancients compared to that of the moderns, see Discours prononcé $a$ l'Athénée royale de Paris 1819 [Speech Given at the Royal Athenee of Paris, 1819], Ecrits politipues [Political Writings] 589, 594 (1997). 
pate one's self from any guardianship, to define in full conscience the measure of one's free agency."13

Curiously, the immense majority of French studies on the separation of church and state do not concern themselves with the United States. ${ }^{14}$ The American conception of the separation of church and state has been little studied in France except by a few specialists. ${ }^{15}$ Favoring the European methods of comparative research that predominate in all disciplines, the usual approach is to compare the French separation of church and state to nonsecular European systems. These regimes collaborate between the state and religion to such a degree that the French model seems an exception, an anomaly that should be suppressed. ${ }^{16}$ Experts on the French separation of church and state seem even to doubt the existence of such a separation in the United States; worse, they refuse

13. In accordance with the terms of Dominique de Villepin, Présentation, in 1905, La Separation des Eglises et de l'Etat: Les Textes Fondateurs [1905, The Separation of Churches and the State: The Foundational Texts] 7, 17 (2004).

14. On laïcité, there is a very abundant bibliography. See, e.g., Jean Baubérot, Laïcité, in Dictionnaire d'Ethique et de Philosophie Moralé [Dictionary of Ethics and Moral Philosophy] 1059 (2004); Jean Baubérot, Histoire de la laïcité en France [History of Secularism in France] (2d ed. 2003); Guy Bédouelle \& Jean-Paul Costa, Les Laïcités à la Française [French Secularism] (1998); Claude Durand-Prinborgne, La Lä̈cité [Secularism], in. Connaissance de Droit [Knowledge of Law] (1996); Marcel Gauchet, La Religion dans la Démocratie: Parcours de la Laïcité [Religion in Democracy: Skimming through Secularism] (1998); Guy Haarscher, La Laïcití [Secularism], (PUF, Coll Que sais-je?, n. 3129, 3d ed., 2004); Jean Morange, Laïité, in Dictionnaire de la Culture Juridique [Dictionary of Legal Culture] 913 (2003); Traité de Droit Français des Religions [Treatise on French Religious Law] 58-60 (Francis Messner et al. eds., 2003). In chapter 5 (Part I), entitled The public regulation of religions in Europe, Messner distinguishes two models of public regulation of religions: the North American model (including, apparently, the United States and Canada) and the European model, a typology that drives him to range secular states (France and the United States, respectively) with those who are not, see id. at 59, §148; Henri Pena-Ruiz, Qu'est-ce que La Laïcité? [What is Secularism?'] (2003); La Laïcité: Textes Choisis ex Présentés [Secularism: Selected and Presented Texts] (2003); Jacques Robert, La Fin de la Laïcité? [ENd of Secularism?] (2004).

15. See, e.g., Denis Lacorne, La séparation de l'Église et de l'État aux États-Unis: Les Paradoxes d'une Laïcité Philo-Cléricale [The Separation of Church and State in the United States: Paradoxes of a Clerical Philosophy], 127 Le Débat [The Debate] 63 (2003); Jean-Pierre Lassalle, La lä̈cité aux Etats-Unis, Un autre regard [Secularism in the United States, Another Look], MÉlanges Georgel 269. See also Le Premier Amendement de la Constitution des États-Unis: Un Modèle Américain des Libertés? [The First Amendment of the United States Constitution: An American Model of Liberties?], 24 La Revue Tocqueville [The Tocqueville Review] 1-134 (2003).

16. See, e.g., Olivier Dord, Laïcité: Le Modèle Français sous Influence Europénne [SecuLARISM: The French Model under European Influence] (2004), available at http://www.robertschuman.org/notes/note24.pdf; see also RamBaud, supra note 3, at 361-404. 
to speak about it on the ground that "religion profoundly permeates society there." 17

That the Americans are a religious people who pride themselves on being so, and that the marks of religion in American society are innumerable, there is no doubt. ${ }^{18}$ Nevertheless, to judge the separation of church and state, one must look not to society, but to the state. In other words, even if religion appears omnipresent in American society, the American state, whether it be the federal state or the federated states, is perfectly secular. It is separated from churches; it is not interested in them and they expect nothing of it. The essential fact that merits explanation is that the American separation of church and state is much more exacting than French lä̈cité, in that it prohibits the state from helping one or all religions in any manner, either in making religious representatives accredited and recognized political interlocutors in political and social dialogue; in putting edifices at their disposition for religious practice; or in financing religious schools-all things that French public authority does to benefit certain religions present in the territory of the Republic. The consequence is that in the United States, as John Witte, Jr. says, religions, churches, or sects are all held up by their own efforts, and all are on equal footing with the others; all are able to count and believe with the power of the word and not the force of obligation; all are able to depend on the faith of their members and not the force of law. ${ }^{19}$ How to explain this? Principally by history.

The United States and France did not arrive at the principle of separation between church and state by the same path ${ }^{20}$ or for the same reasons. In France, the separation of church and state was a counteroffensive of the newborn Third Republic against its enemies; it nourished itself in ideological opposition to the spirit of the counter-revolution, which spawned the intransigent Catholicism of

17. Stasi Report, supra note 4, at 20.

18. See, e.g., André Kaspi et al., La Civilisation Américaine [American Civilization] 22758 (2004); Isabelle Richet, La Relicion aux Etats-Unis [Religion in the United States] (2001).

19. John Witte Jr., Religion and the American Constitutional Experiment: Essential Rights AND Liberties I (2000).

20. On the contribution, little known in France, of American Protestant churches on the historical formation of the principle of separation of church and state, see Marci A. Hamilton, Les Origines Religieuses de la Clause Américaine de Non-établissement [Theological Sources of the Principle of Church and State in the United States], in LA Conception, supra note *, at 71. 
the nineteenth century. ${ }^{21}$ "Laicite" was the slogan that inspired republicans, Protestants, Jews, and Freemasons, all of whom took alarm at the return of the dogma of pontifical infallibility reaffirmed by Vatican I (1870). These reformers focused on the issue of education because it was through the schools that religious groups, especially the powerful Jesuits, professed their antidemocratic doctrines and exercised their influence in the most profound and lasting manner. Laïcité was a word around which all who battled for "taking the soul of the French youth away from them" rallied, as Jules Ferry had promised in his discourse at Epinal, April 23, 1879."2

Unlike the French laïcité, which was nourished by a revolutionary ideology tending to substitute a civil religion for a dominant one, American separation of church and state was born of true experience, soberly enunciated by Voltaire and admirably understood by Jefferson and Madison. This truth, that "the ambition to dominate the minds is one of the strongest passions," 3 did not take long for Americans to comprehend. Radical Protestants who had fled England to come to America "to worship God in liberty," as Tocqueville has well said, ${ }^{24}$ became, after settling on the conquered territory, as dominating as those they had fled. Each church (the Puritans in New England, the Anglicans in the South) did not wait, once settled, to install its own religion as the established religion. In certain colonies, notably in New England, the persecuted of yesterday persecuted in their turn, provoking the creation of new colonies by a schism with the founding colony, as the oppressed followed the example of their ancestors. In this way, Rhode Island was founded in 1636 when Roger Williams led dissidents from Puritanism to break away from the Massachusetts territory; Connecticut was founded by Puritan purists.

On June 12, 1776, Virginia adopted the first declaration of rights ever written, drafted by George Mason. The Virginia Declaration of Rights (Virginia Declaration) demanded "the free exercise of religion, according to the dictates of

21. See Francis Bouthillon, De la lä̈cité [On Secularism], 108 Commentare [Commentary] 1121-23 (Winter 2005).

22. The passage is cited by Jean-Michel Gaillard, L'invention de la Lä̈cité (1598-1905) [The Invention of Secularism (1598-1905)], in 1905, La Separation des Eglises et de L'Etat: Les Textes Fondateurs [1905, The Separation of Churches and the State: The Foundational Texts], supra note 13 , at 28.

23. Volraire, Examen Important de Milord Bolingbroke ou Le Tombeau de Fanatisme [Important Examination of Lord Bolingbroke or the Tomb of Fanaticism], in MéLANGEs 1019 (1961).

24. Alexis de Tocqueville, Democracy in America 35 (J.P. Mayer ed., George Lawrence trans., Anchor Books 1969) (1835-1840). 
conscience." 25 This language echoed the writings of Locke ${ }^{26}$ and intellectual thoughts formed in favor of religious tolerance. The first version of the Virginia Declaration codified religious tolerance in these terms:

That religion, or the duty which we owe to our Creator, and the manner of discharging it, can be directed only by reason and conviction, not by force or violence; and therefore all men are equally entitled to the most complete exercise of conscience, as well as complete freedom of worship, according to the dictates of conscience; and they must not be impeded or punished by authorities, so long as religion does not serve as a pretext to trouble the peace, happiness or stability of society; and that it is the mutual duty of all to practice Christian forbearance, love, and charity toward each other.

This tolerance marked a great step forward, but Madison thought that it did not go far enough. Influenced by the ideas of the great philosophers, Madison thought that "tolerance" should be changed to "free exercise" or "free practice." The new vocabulary marked a radical change in spirit. For Madison, religious liberty should not be the result of a concession of the state or of an established church; religious liberty should be a right, the inalienable and natural right of each citizen. The Virginia Declaration (article 16), in its modified version of 1791, proclaimed:

[R]eligion, or the duty which we owe to our Creator, and the manner of discharging it, can be directed only by reason and conviction, not by force or violence; and therefore all men are equally entitled to the free exercise of religion, according to the dictates of conscience; and that it is the mutual duty of all to practice Christian forbearance, love, and charity toward each other. ${ }^{27}$

25. The VIRGinia DeClaration of Rights $\$ 16(1776)$, available at http:/www.constitution.org/ bcp/virg_dor.htm.

26. John Locke, Letter on Tolerance (Paris, Nathan 2003) (originally published in 1689, 1690, 1692).

27. The Virginia Declaration of Rights, supra note $25, \S 16$. 
The right of free exercise of religion proclaimed by the Virginia Declaration of 1791 went well beyond simple religious tolerance; it was the first proclamation of the right of religious liberty.

The real right to practice the religion of one's choice was followed by a decisive battle to extirpate state religion, notably in Virginia, where the Anglican Church was the established religion. Madison played a key role in the fight, and was able to persuade the Virginia legislature in 1786 to adopt a bill prepared by Thomas Jefferson regarding the establishment of religious liberty. Both fought relentlessly to make it understood that state financial aid to one or all religions was a grave error, because it obligated citizens to support by tax a faith to which they did not subscribe, which constituted a violation of the natural right of religious liberty. "Almighty God hath created the mind free," affirmed Jefferson's bill to establish religious freedom in Virginia, and "to compel a man to furnish contributions of money for the propagation of opinions which he disbelieves and abhors, is sinful and tyrannical." 28

Madison and Jefferson were greatly aided in their fight against state religion in Virginia by Baptists, Presbyterians, Quakers, and all other faithful of the dissident churches. During the period of the first Great Awakening (1728-1790), which marked the renewal of faith in the eighteenth century, religious fervor became intense in the United States. New forms of religious expression ruled the day. Their message, the promise of salvation only by Christ, elicited personal and emotional responses in the homes of thousands of Americans. The evangelical fervor of the Great Awakening touched all of society, across partisan lines, and eroded traditional support for the privileges of the established church. People began to consider religion as an affair of unrestricted choice, purely personal, and the church as a place of unimpeded administration. The alliance of church and state, previously considered normal, was more and more regarded as not only fatal to liberty of conscience, but even disastrous to all religions. The suppression, in 1786, of the Anglican Church as the state church in Virginia marked a great victory and is an essential event in the history of religious liberty in the United States. When the First Amendment was ratified in 1791, the Anglican Church had been suppressed in all other states that had an established religion (with the exception of Maryland). The Congregationalist movement in Connecticut remained the state religion until 1818. The institution of estab-

28. Thomas Jefferson, $A$ Bill for Establishing Religious Freedom, 12 June 1779, in 5 THE Founders' Constitution 77 (Philip B. Kurland \& Ralph Lerner eds., 1987). 
lished religion disappeared in 1833, when the constitution of Massachusetts was revised to suppress the state religion.

The historic evolution gave the American version of the principle of separation of church and state a very different face from that in Europe. ${ }^{29}$ The multiplicity of churches and the proliferation of sects rendered possible by the "disestablishment" of all established religions, coupled with the affirmation of an enduring right of man to believe as he wishes and to freely practice the rites of his faith, were the basis upon which pluralism was built, an essential characteristic of American society that renews itself perpetually by the play between the Establishment and Free Exercise Clauses. While the Establishment Clause prohibits the formulation of a principle of unity, the Free Exercise Clause renews each day the principle of diversity. In the United States, as no religions can be established, none can be menacing; inversely, as no belief can be impeded, none is truly protected. This extraordinary interplay between the clauses of the First Amendment, which creates a perpetual pluralism, does not modify the consequences of the separation of church and state, insofar as in the United States, as well as in France, the state is obligated, on the one hand, to observe a principle of strict neutrality vis-à-vis all religions and, on the other hand, to guarantee the free exercise of religion. However, the pluralism that exists in the United States modifies the reach of the separation between church and state; it renders this separation more rigid and categorical. One can measure this by the more exigent neutrality that the Supreme Court imposes on the federal government or on the federated states vis-à-vis religions (Part I) and the greater liberty it tends to recognize for each individual to manifest the religious convictions of his choice, though always within the bounds of the law (Part II).

\section{The Principle of State Neutrality}

In the United States, the principle of separation of church and state requires the state to adopt perfect neutrality toward all religions. Legal scholars do not distinguish, as in France, between positive and negative neutrality. ${ }^{30}$ The neu-

29. See Douglas Laycock, Church and State in the United States: Competing Conceptions and Historic Changes, 13 Ind. J. Global Legal Stud. 503 (2006).

30. See Philippe Ségur, Traité de Droit Français des Religions [Treatise on French ReliGIOUS LAw] $§ \S 852-862$. 
trality of the state is always negative in the sense that the state can never oppress nor advance a religion. In the United States, the neutrality of the state toward religion or religions has a fixed nature, so to speak. The task of absolute neutrality of the state toward religion or religions is more than a constitutional principle; it has become a dogma of American political philosophy. The state must never take a position regarding a belief, and must treat all religions as equal (Subpart A); but beyond this, the state has an obligation not to provide aid to a religion or religions, and not to treat one better or worse than another (Subpart B).

\section{A. Equality of All Religions}

In French religious law, religions are in a situation akin to the animals on Orwell's farm: some are more equal than others. This situation, often criticized on principle, ${ }^{31}$ is explained by history. ${ }^{32}$ The separation between church and state was achieved in 1905, in opposition to Catholicism, which was, at the time, the dominant religion. It was not possible, for various legal and social reasons, to render Catholicism equal in status with other religions, in particular as that equality concerned worship edifices. Another differentiating factor in French religious law comes from the fact that there are beliefs and rites that French law does not recognize as true religions but as cults that, while formally treated like other religions, ${ }^{33}$ are nevertheless subject to specific penal measures. ${ }^{34}$ Nothing like this exists in the United States, as the Establishment Clause renders all religions equal with the others. As the Supreme Court said in 1982, "The clearest command of the Establishment Clause is that one religious denomination cannot be officially preferred over another." ${ }^{35}$

More than two thousand denominations exist in the United States, each identified as a religion, without counting the innumerable independent

31. See, e.g., Stéphane Pierré-Caps, Les "Nouveaux Cultes" et le Droit Public [New Faiths and Public Law], 1990 Revue du Droit Public [Public Law Review] 1073; Pierre-Henri Prélot, Les Religions et l'Égalité en Droit Français [Religions and Equality in French Law], 2001 Revue du Droit Public [Public Law Review] 737.

32. As the Conseil d'Etat has well explained, the separation of church and state in France is constructed on the foundation of Catholicism. See Un siècle de Laïcité [A Century of Secularism], supra note 1 , at 316 .

33. Dominique Latournerie, Sectes et Laïcité [Cults and Secularism], 2004 Revue du Droit Public [Public Law Review] 1327.

34. See the June 12, 2001 law that created the "mental manipulation" crime.

35. Larson v. Valente, 456 U.S. 228, 244 (1982). 
churches and worship communities. In the eyes of the law and judges, all have equal dignity; all can claim the protections of the First Amendment, whether it is the Santeria religion (which practices animal sacrifice), ${ }^{36}$ or the Native American religion that requires its members to smoke the peyote plant ("the plant that amazes the eyes," as the Aztecs called it) to purify their moments of prayer. ${ }^{37}$ This protection has not always been enforced in practice. In the nineteenth century, religions were not equal in the United States. The Christian religion was the dominant religion, and everyone agreed with the great constitutional scholar and Supreme Court Justice Joseph Story, who interpreted the spirit of the First Amendment in these terms: "The States must be, in principal, free to encourage the Christian religion in so far as their politics and their laws are not incompatible with freedom of conscience and freedom of worship." 38 In other words, the states were free to privilege the Christian religion, to the point that they codified the precepts of the Bible in their laws during the entirety of the nineteenth century and through the middle of the twentieth, because, according to the jurisprudence of Barron v. Baltimore, ${ }^{39}$ the religious clauses of the First Amendment did not apply to them. They took advantage of that freedom, and it is because of all these laws, inspired by the scriptures and adopted in the name of morality, that America became a White-Anglo-Saxon-Protestant (WASP) society, a society that knew its apogee in the middle of the last century. The Christian religion dominated society, and America was a Puritan society.

Today, the Christian religion in the United States is one religion among many. It has been put on the same level as all other confessions, beliefs, or diverse sects. It does not receive any particular consideration. It has been rendered commonplace. American society has become a multiconfessional, hence multicultural, society, which shines beyond American borders and imposes itself as the societal model of the twenty-first century. This evolution is the result of all sorts of factors, including racial diversity, new currents of immigration, and the influx of populations raised in other cultures. ${ }^{40}$ This is not the place to conduct a

36. See Church of the Lukumi Babalu Aye, Inc. v. City of Hialeah, 508 U.S. 520,525 (1993).

37. Employment Div., Dep't of Human Res. of Oregon v. Smith, 494 U.S. 872, 874 (1990).

38. Joseph Story, Commentaries on the Constitution of the United States $\$ 988$ (Carolina Academic Press 1987) (1833).

39. See generally Barron v. Mayor of Baltimore, 32 U.S. (7 Pet.) 243 (1833).

40. For a general study of the consequences, see Denis Lacorne, La Crise de L'Identité Américaine: Du Melting-Pot au Multiculturalisme [The Crisis of American Identity: On the Melting Pot of Multiculturalism] (1997). 
census. But one thing is certain: The diminishment of the dominant role of Christianity brought about by clear, patient, and continued jurisprudence by the Supreme Court, which functions to remove all privileges, advantages, and social usages of Christianity, played a decisive role in these societal transformations.

All of this commenced with the incorporation of the religious clauses of the First Amendment ${ }^{+1}$ achieved by two decisions: the first, regarding the right of Jehovah's Witnesses to preach their tenets in public thoroughfares; ${ }^{42}$ the second, concerning the use of public funds to reimburse parents of parochial school students for transportation expenses. ${ }^{+3}$ Once the religious clauses of the First Amendment were applied to the states, the states no longer had the luxury of keeping religious affairs in their exclusive domain; the margin of appreciation from which they had previously benefited dwindled. The social consequences of this evolution of law were considerable. American society being naturally drawn to religion, the white Christian majority in power in the states became all the more right wing and more cooperative with one another. Failing to dominate political life because of the separation of church and state that had been growing since the beginning of the nineteenth century, the Christian religion dominated social life instead, particularly in the schools. In certain states, religion determined school programs; laws prohibited the teaching of evolution or, at the very least, required that teachers present the Biblical theory of creation alongside the theory of Darwinism. All these local particularities (geographically limited) fell before the Court. ${ }^{44}$ This is nevertheless not essential to understanding the erosion and loss of legal status of the Christian religion.

The Court dismantled the status of the dominant religion (and therefore culture), which upheld that Christian religion in American society, when it decided to declare unconstitutional two of the most representative institutions of the Christian domination of society: prayer in public schools and Nativity scenes in municipalities at Christmas. The decisions concerning prayer in public school

41. The doctrine of incorporation is a technique of American constitutional law invented to remediate insufficient protection of the rights and liberties in the initial federal system. It reads the word "liberty" inscribed in the Due Process Clause of the Fourteenth Amendment ["No state shall ... deprive any person of life, liberty, or property, without due process of law"] as referencing, in American terminology, the incorporation of all (or, debatably, part) of the rights and liberties contained in the first eight amendments to the Constitution, which consists of the Bill of Rights, and, at its origin, applied only to the federal government. U.S. Const. amend. XIV, $\S 1$.

42. See Cantwell v. Connecticut, 310 U.S. 296 (1940).

43. Everson v. Bd. of Educ. of Ewing Twp., 330 U.S. 1 (1947).

44. See Epperson v. Arkansas, 393 U.S. 97 (1968); Edwards v. Aguillard, 482 U.S. 578 (1987). 
displayed a rare intransigence. No manifestation of devotion, even of meditation, found grace before the justices, so long as it appeared to be sponsored in one manner or another by the state. The Court uniformly censured all organized prayer by public authorities, whatever its form, whether confessional prayer, ${ }^{45}$ Bible verse readings, ${ }^{46}$ minutes of silence, ${ }^{47}$ or a sermon at an awards ceremony. ${ }^{48}$ This jurisprudence raised a tempest of protest. Dozens of constitutional amendments were proposed in the House of Representatives and the Senate to reestablish the tradition. None were successful. Undaunted, the Court expanded this jurisprudence to prohibit a moment of solemnity, led by a student chosen by the school, at the beginning of a football game..$^{49}$ After removing the Christian religion from public schools, the Court also removed it from public streets and buildings by declaring symbolic displays such as Nativity scenes in municipalities unconstitutional. Today, the display of a crèche is not acceptable to the justices unless it is displayed among other secular symbols (such as a Christmas tree, Santa Claus, the North Pole, Santa's sleigh and reindeer, the embellishment of figurines representing a clown, an elephant, and a bear) and non-Christian symbols (a Jewish menorah), so that it is no longer anything more than an island of Christianity in an ocean of atheism or Judaism and thereby loses its essential religious signification. ${ }^{50}$

The jurisprudence of the Court on school prayer and Nativity scenes was decisive in the Christian religion's loss of its status as the preferred religion of American society. The success of the enterprise stemmed from the fact that, with great intelligence, the Court carried out its efforts to normalize the Christian religion in institutions in the public sphere: schools, public buildings and places, the town center, and in areas open to the public. On the other hand, the Court took care not to attack the status of the Christian religion as the preferred reli-

45. See Engel v. Vitale, 370 U.S. 421, 430 (1962).

46. Sch. Dist. of Abington Twp. v. Schempp, 374 U.S. 203 (1963).

47. Wallace v. Jaffree, 472 U.S. 38 (1985).

48. See Lee v. Weisman, 505 U.S. 577 (1992).

49. See Santa Fe Indep. Sch. Dist. v. Doe, 530 U.S. 290 (2000).

50. See Lynch v. Donnelly, 465 U.S. 668 (1984). Christian religious symbols are not treated in exactly the same manner as symbols of other religions. A nativity scene installed by itself on the steps of a government building, set atop a banderole proclaiming "Gloria in Excelsis Deo" is an unacceptable public display of a religious symbol, unless a Jewish menorah is placed in the street next to a Christmas tree. Taken together these symbols do not receive the same censure as a nativity scene alone. The Court explains its position by noting that a menorah cannot be considered exclusively a religious symbol. County of Allegheny v. ACLU, 492 U.S. 573, 613 (1989). 
gion of Americans, when manifested outside the public sphere, such as religious instruction outside of the public schools. ${ }^{51}$ Similar choices inscribed themselves in the logic of the political jurisprudence, announced by the Court in $1947^{52}$ and enacted notwithstanding changes in the majority on the bench, that was to bring the dominant religion to the rank of ordinary religion.

The normalization of Christianity permitted the Court to elegantly resolve the apparent contradiction between Constitutional provisions that prohibited the state from recognizing an established religion and the innumerable religious manifestations that punctuate the life of American institutions (the chaplain of Congress, the President swearing on the Bible, the phrase "God Save the United States and this Honorable Court!" that opens judicial audiences, the inscription "In God We Trust" on coins and bills). A deputy of the Nebraska legislature gave the Court the occasion to rule on this apparent contradiction, when he questioned the constitutionality of a law authorizing the use of public funds for the remuneration of the state legislature's chaplain. The Court rejected his request for the reason that the practice of opening a legislative session with a prayer had been followed by colonial legislatures and continued by the Continental Congress after 1774. It reasoned also that the consistent practice of remunerating a chaplain to perform this function was ratified by Congress on September 25, 1789, three days before the definitive text of the Bill of Rights was agreed upon, so that not only did the authors of the Bill of Rights implicitly approve the practice, but necessarily instituted a chaplain. It is possible today to say that uninterrupted practice during more than two centuries has inscribed prayer in legislatures in "the fabric of our society." 53 But the decisive point, it seems, is

51. Religious instruction cannot be provided within the walls of the public school. See Illinois ex rel. McCollum v. Bd. of Educ., 333 U.S. 203 (1948). It is nevertheless constitutionally possible for a public school to agree to provide after-school religious instruction to its students. See Zorach v. Clauson, 343 U.S. 306 (1952).

52. In the Everson v. Board of Education holding, the Court announced the direction which it would henceforth take regarding the Establishment Clause in these terms: The "establishment of religion' clause of the First Amendment means at least this: Neither a state nor the Federal Government can set up a church. Neither can pass laws which aid one religion, aid all religions, or prefer one religion over another." Everson v. Bd. of Educ., 330 U.S. 1, 15 (1947). In other words, there could not or, more exactly, there could no longer, be any preferred religion in the United States.

53. Marsh v. Chambers, 463 U.S. 783, 792 (1983). In construing the meaning of the Establishment Clause, the Court clearly recognizes that its analysis is driven by "[the] Nation's history." Van Orden v. Perry, 125 S. Ct. 2854, 2861 (2005). It is also driven by the "context" of the particular monument or display at stake. McCreary County v. ACLU, 125 S. Ct. 2722, 2734 (2005) (quoting Edwards v. Aguillard, 482 U.S. 578, 594-95 (1987)). 
that only by reducing Christianity to the status of ordinary religion could the Court deadlock imply that prayer had become not empty of any religious meaning, but empty only of a Christian message, or as the Court said, empty of "anyone, or . . any other, faith or belief." ${ }^{\text {5 }}$

All religions find their place in the American public sphere, but none is more meaningful than another. All have equal dignity, all have the same value, and none can dominate another. Thanks to this principle, there cannot be in the United States the situations that are frequent in other parts of the world, where a dominant religion opposes a minority religion; these situations create what politicians call a zero-sum game, in which everything that one party gains, the other loses. ${ }^{55}$ Today, at the end of this revolution, American society is not less impregnated with religion than it was, and Tocqueville's thought that "religion... must be considered as the first of America's political institutions" 56 is still current. But American society is no longer Christian, and even less Protestant.

\section{B. Prohibition of Any State Aid to Religion}

As soon as there is no preferred religion and all religions are equal with each other, all must be treated equally. Equal treatment among all religions combined with the demand for absolute neutrality, as required by the Establishment Clause, implies that neither the federal government nor the states may aid, sustain, or favor one religion over another, even if the cause is noble and just (for example, aiding mentally handicapped children of Jewish Orthodox parents by regrouping them in a special district developed to aid their handicap)..$^{57}$

The crystallizing point in the numerous difficulties raised by the prohibition of all state aid to religion was the issue of financial aid to religious schools. The jurisprudence of the Supreme Court has passed through many phases in the interpretation of the Establishment Clause and the principle of neutrality it invokes. The strict, even rigid, interpretation adopted at the end of the 1940s was succeeded, in the 1980 s, by a more flexible one that, without putting back in place the

54. Marsh, 463 U.S. at 794-95 (alteration in original).

55. See Kenneth D. Wald, Separation and Interaction: Religion and Politics in the United States, 2 U.S. SOCIETY \& VALUES 29, 31 (1997), available at http://www.usembassy.iv/pdf/ej/ijse0397.pdf.

56. ToceueviLle, supra note 24 , at 338 .

57. "[W]hatever the limits of permissible legislative accommodations may be ... it is clear that neutrality as among religions must be honored." Bd. of Educ. v. Grumet, 512 U.S. 687, 706-07 (1994). 
classic meaning of the First Amendment, summarized by Jefferson in what is today his quasi-canonical formula of the "wall of separation" (that in announcing that Congress shall "make no law respecting an establishment of religion, or prohibiting the free exercise thereof," the American people wished to establish "a wall of separation between church and State"), ${ }^{58}$ sensibly narrowed the reach of it.

In 1947, the Everson decision adopted a strict interpretation of the First Amendment, often qualified by the American doctrine of "separationism." 59 According to Justice Black, the Establishment Clause "means at least this .... No tax in any amount, large or small, can be levied to support any religious activities or institutions, whatever they may be called, or whatever form they may adopt to teach or practice religion." ${ }^{60}$ The Court applied this doctrine of strict separation between church and state in numerous cases until, in 1971, it consolidated all the different criteria it used in one principle decision, Lemon v. Kurtzman, ${ }^{61}$ which enunciated a doctrine founded on three prongs. The case arose from two state laws, one in Rhode Island and the other in Pennsylvania, allowing budgetary contributions to salaries of teachers in private schools, the vast majority of which were Roman Catholic-affiliated. In Rhode Island, the contribution was in the form of an annual salary supplement of 15 percent; in Pennsylvania, the law authorized the state superintendent of public instruction to purchase certain secular educational services from nonpublic schools, directly reimbursing those schools solely for teachers' salaries, textbooks, and instructional materials. The Court held that, to pass muster under the Establishment Clause, a state law must meet three prongs: (1) the statute must have a secular legislative purpose; (2) its principal or primary effect must be one that neither advances nor inhibits religion; and (3) the statute must not foster an excessive government entanglement with religion. ${ }^{62}$ In this case, the Court held that the

58. Letter of Thomas Jefferson, January 1, 1802, written in response to an associate in Danbury, Connecticut, a Baptist, who asked Jefferson to declare, in his capacity as the President of the United States, a national day of prayer. Letter from Thomas Jefferson to Nehemia Dodge and Others (Jan. 1, 1802), in Thomas Jefrerson: Writings 510 (1984). It is probable that the phrase "wall of separation" refers to the wall which, in the Bible, separated the Garden of Eden from the terrestrial world. The metaphor was used by preacher Roger Williams, who founded the colony of Rhode Island in the sixteenth century.

59. See, e.g., Daniel O. Conkle, Constitutional Law: The Religion Clauses 176 (2003); see also Erwin Chemerinsky, Constitutional. Law, Principles and Policies 977-78 (1997).

60. Everson v. Bd. of Educ., 330 U.S. 1, 15-16 (1947).

61. Lemon v. Kurtzman, 403 U.S. 602 (1971).

62. Id. at 612-13. 
two laws did not meet this test, particularly the third prong, because the cumulative impact of the states' involvement in the financial administration of private schools was an excessive entanglement with religion.

The Lemon doctrine was applied to innumerable cases involving the Establishment Clause with greater or lesser enthusiasm, and more or less ingenuity. ${ }^{63}$ From the 1980s, the Court was increasingly criticized, notably by conservative judges, who ceaselessly reproached the Court for its rigidity. Behind this criticism, there were great financial stakes, as well as concern about profitability and efficiency. Always vigilant where public funds are concerned, conservatives hold that private schools perform better than public schools, and they adeptly spot policies that encourage private schools, which the Lemon doctrine expressly prohibits. They have had an influence, and jurisprudence today has adopted an infinitely less distinct line than the one Lemon prescribes. The Court no longer manifests hostility to the principle of state aid to private schools. Today, the Lemon case certainly has authority, but that authority is significantly weakened. The Establishment Clause no longer requires, as before, a policy of strict separation between church and confessional schools, but rather a policy of neutrality; let us say, less contracted. This evolution especially related to the interpretation of the concept of entanglement of the state and religion, which was the third prong of the Lemon test and which the Court finally modified in two distinct ways.

In the first case, the Court abandoned the method of presumptions inspired by the Lemon case, which it had applied during the 1970s and 1980s to decide whether state aid should be considered contrary to the principle of separation of church and state. ${ }^{6-1}$ In effect, the Lemon doctrine prohibited aid to confessional schools in the form of budgetary subsidies or financial grants. Today, if the aid is formally neutral, meaning the aid is not granted directly to private or confessional establishments but is open to both private and public establishments, the Court seems to no longer want to censor these nondiscriminatory state aid pro-

63. See Daniel O. Conkle, Expression et Symbolisme Religieux dans la Tradition Constitutionnelle Américaine: Neutralité de l'État, mais pas Indifference [Expression and Religious Symbolism in the American Constitutional Tradition: State Neutrality but not Indifference], in La Conception Américaine de la Laïcité [The American Conception of Secularism] 153, 156-57 (Élisabeth Zoller ed., 2005).

64 . From the 1960s forward, the Court no longer considered using public funds to pay professors in religious schools contrary to the Establishment Clause. See Agostini v. Felton, 521 U.S. 203 (1997). Already in 1993, the Court had ruled that a school district could, without violating the Establishment Clause, decide to pay a sign language interpreter to aid a deaf student at a religious school. See Zobrest v. Catalina Foothills Sch. Dist., 509 U.S. 1 (1993). 
grams, even if they benefit religious schools and even if, in practice, the programs give a quasi-exclusive advantage to them. Recently, in Mitchell v. Helms, ${ }^{65}$ the Court held that a program that provided financial aid to all educational establishments to buy equipment and computers for students was not contrary to the Establishment Clause.

In the second place, states today have found ways to bypass the prohibitions of Lemon. Favoring legal economic theory and analysis of the rationality of public choices, they know now that there are two forms of aid: direct and indirect. The first is a direct transfer of resources to schools, public funds passing from the coffers of the state to private coffers. This is certainly more problematic from a constitutional view. The second is much less problematic in that it operates as only an indirect transfer, where public funds do not go to schools, but rather to individuals. Individuals then use them as a school voucher, through which they are free to apply the money to the public or private school of their choice. If these resources benefit religious organizations or schools, it is the effect of a purely private choice, for which the individual is responsible and not the state. State policies that valorize true private choice and that, in so doing, indirectly benefit confessional schools are not contrary to the principle of separation of church and state. ${ }^{66}$

At the end of this evolution, it seems that the principle of state neutrality toward religion, which is in the United States (as in France) the first manifestation of the principle of state secularism, does not mandate, as before, hostility toward all forms of state aid to religious schools. In France, this hostility was neutralized by the Debré law of December 31, 1959, which put an end to the school quarrel by permitting private confessional establishments to make a contract with the state. ${ }^{67}$ In the United States, the Lemon case in the 1970s marked the apogee of that hostility. Today, that hostility no longer stirs the spirit as in the past, and it is certainly on the decline. There are numerous reasons, of which the unequal performance of the public school system throughout the United States is not the least. But it is more and more difficult to privilege the principle of separation of church and state over that of equality.

The revolution that began in the 1950s had indirect consequences on the socalled "wall of separation" set up by constituents between churches and the state. Since all must be treated equally whether they are religious or not, it becomes

65. Mitchell v. Helms, 530 U.S. 793 (2000).

66. See Zelman v. Simmons-Harris, 536 U.S. 639, 649 (2002).

67. See PrÉLot, supra note 14 , at 1187, $\$ \S 2844-2878$ (devoting developments to private confessional teaching). 
very problematic to duly justify the survival of discriminatory administrative regimes for denominational schools. To refuse schools the advantages of public manna solely because they are confessional results in the perception that the liberty to practice the religion of one's choice and to give one's children a religious education is being attacked. It is therefore necessary, in order to truly take this last liberty seriously, to soften the principle of neutrality and admit that it prohibits certain policies, but not all. There is no doubt that the obligation of neutrality prohibits the states from establishing a church or endorsing a particular religion or interfering with a religion. As for the rest, the Court says, "there is room for play in the joints. ${ }^{168}$ In other words, it is necessary to apply the principle of separation without bringing excessive attacks on individual liberties, including that to give one's children an education that conforms to one's beliefs.

In conclusion, if the separation of church and state still signifies a policy of neutrality toward religion, it is no longer a strict policy of neutrality, which bordered on hostility, as in the past. Now, it allows for the benevolent neutrality of the French laïcité. For if denominational schools receive aid, it is because all schools are similarly aided; the assistance can never be discriminatory. Then the new approach to neutrality consists of making assistance to religious schools the choice of the individual and not the state. This transformation, realized by granting a voucher to those interested, in place of a direct budget subsidy to the school, is the decisive element. Twenty years have already passed since the Court explained in substance that public money could go to religious education without violating the Constitution, so long as the destination was the result of the free and individual choice of citizens. ${ }^{69}$ Once the aid is indirect, then it becomes constitutional. As the Court recently said, "Under our Establishment Clause precedent, the link between government funds and religious training is broken by the independent and private choice of recipients." ${ }^{70}$

68. Walz v. Tax Comm'n, 397 U.S. 664, 669 (1970) (validating tax exemptions by the State of New York to all worship edifices).

69. See Mueller v. Allen, 463 U.S. 388 (1983). The Supreme Court in a 5-4 decision held that a fiscal deduction for the purchase of school supplies which advantaged religious schools did not violate the Establishment Clause because the benefit was open to all parents of students, whether in public or religious schools. See also Witters v. Washington Dep't of Servs. for the Blind, 474 U.S. 481 (1986). Here, the Court unanimously held that a subvention to young blind students to aid them in their studies could be used at a religious school without violating the Establishment Clause, so long as the benefit resulted from a private choice rather than direct state subsidy.

70. Locke v. Davey, 540 U.S. 712, 719 (2004). 
If, therefore, public funds can benefit religious schools without constitutional orthodoxy suffering as a result, it is at last because the citizens wish that it be so. As long as their choice is truly free, not forced and not guided by the state, the Court feels that it is not up to it to decide whether to give or refuse the aid. In its way, the school voucher is the greatest homage one can render to religion and to the right of man to worship following the dictates of his own conscience, but it also signifies the repudiation of any educational goal and any control over the use of public funds. ${ }^{71}$ The same consequence that, in France, would throw the heirs of Condorcet ${ }^{72}$ into the greatest distress, by no means moves the judges of the Supreme Court, whose jurisprudence fits perfectly in the tradition of American liberal thought: Private choices are always superior to public choices, and the liberty of the citizens must always prevail. Vox populi, vox Dei!

\section{RELIGIOUS LiBERTY}

In the United States, religious liberty is guaranteed by the Free Exercise Clause, which prohibits Congress (and, since the Cantwell ${ }^{73}$ case, state legislatures) from making any law that would, in effect, prevent the free exercise of religion. The Free Exercise Clause is tied to the Establishment Clause: The intertwinement between the two is essential in order to understand the degree of protection that religious liberty is accorded. This liberty can be protected by state authorities only insofar as that protection or assistance does not lead to the establishment of one religion. The notion of "establishment of religion," as explained

71. The obligation of absolute neutrality of the state-which makes it a mute state-is the core of the jurisprudence of the Supreme Court on freedom of speech, which systematically censures every policy, every law, every decision of the state which could express the least position on an individual expression in the public sphere. The freedom of expression confirms and reinforces religious freedom when the Supreme Court prohibits a town council from denying the Ku Klux Klan the right to express itself symbolically in the public sphere by erecting a religious sign like the cross, even if, in fact, as well by its form as by its sponsors, the aforementioned symbol can be interpreted, not as a symbol of universal love, but as a symbol of superiority and racial hatred. See generally Capitol Square Review \& Advisory Bd. v. Pinette, 515 U.S. 753 (1995).

72. Condorcet (1743-1794) is regarded in France as a founding father of free and equal public education.

73. Cantwell v. Connecticut, 310 U.S. 296 (1940). 
above, is widely understood ${ }^{74}$ to mean that religious liberty, like all other liberties, but perhaps even more than the others, is always a negative liberty. It imposes on the state only the obligation to refrain from acting, not to act; it imposes prohibitions, but it does not demand benefits. In this, it dissociates itself from the French,${ }^{75}$ and largely European ${ }^{76}$ tradition, which tends to give the state the responsibility to guarantee the efficacious exercise of liberties. No such guarantee is possible, even envisioned, in the United States. Religious liberty is, firstly, a negative liberty that prohibits discrimination on account of religion (Subpart A). It is not, except in embryonic form, a liberty that calls for positive obligations on the part of the state, and the obligation for reasonable accommodation falls far short of what it implies in France (Subpart B).

\section{A. Prohibition of Discrimination}

In the United States, religious liberty is more than the liberty of conscience or worship. It is also a manner by which the individual can affirm and express by means of religion that he is free to define a personal experience of salvation, knowledge, and surpassing of self. Different from Europe, where it is exerted via a clergy with the assistance of institutions, religious freedom in the United States is understood to be the result of a personal construction of the individual. ${ }^{77}$

74. It is even so widely understood that, if it does not outright prohibit, it casts doubt on the constitutionality of the religious engagement of the politician. A law, a policy, or a decision inspired by the religious convictions of its author could be against the Establishment Clause. The debate is only beginning, but it already engenders strong feelings in the United States. It has considerable implications not only on lawmaking, but on political decisions, such as the appointments of magistrates. For a stirring plea in favor of the freedom of the legislator to inscribe in the law that which he believes to be in the interest of all, see the report of Michael J. Perry, Why Religion in Politics Does Not Violate la Conception Americaine de la laïcité, 13 Ind. J. Global Legal Stud. 543 (2006).

75. Notwithstanding the suppression of state subsidies to religions realized by the law of separation of church and state, article 2 of the law of 1905 provided that certain expenses could receive subsidies from the state, departments or municipalities: expenditures relating to services of chaplaincy and those intended to ensure the free exercise of worship in publicly-owned establishments such as colleges, schools, nursing homes, asylums, and prisons.

76. See Frédéric Sudre, Droit européen et international des droits de l'homme [European and International Human Rights Law] 228-30, If 163-64 (6th ed. 2003) (demonstrating the audacious jurisprudence of the European Court of Human Rights on the notion of a "positive obligation").

77. Frederick Mark Gedicks, Religious Exemptions, Formal Neutrality, and Laïcité, 13 IND. J. Global Legal Stud. 473 (2006) (analyzing in detail this heavy tendency of American society, almost exacerbated today, and its consequences on the mode of religious freedom). 
The Protestant foundations of society derive originally from an old and almost fierce tradition of religious individualism. Already in the eighteenth century Jefferson could say, "I am a sect myself," and Thomas Payne, "Imly mind is my church. ${ }^{" 78}$ Not only is each person free to have or not have a religion, but each is free to denominate a religion, no matter what belief, and to adopt it with all the rights of free exercise that are attached.

The Supreme Court has never given a constitutional definition of religion to apply to the Free Exercise Clause. On the other hand, it has chosen a legislative definition to apply to the federal law of 1958 regarding military service and conscientious objection. The federal legislature provided that exemptions from active military service and combat units could be granted for conscientious objection based on religion, religion being defined as "[an] individual's belief in a relation to a Supreme Being." 79 The question arose as to whether atheists could avail themselves of the exception. The Court responded in the affirmative, taking a very liberal interpretation of Congress's definition. In 1965, in United States v. Seeger, it held "the test of belief 'in a relation to a Supreme Being' is whether a given belief that is sincere and meaningful occupies a place in the life of its possessor parallel to that filled by the orthodox belief in God of one who clearly qualifies for the exemption." ${ }^{80}$ The Court never applied the Seeger definition in a constitutional matter. The Free Exercise Clause protects, therefore, in principle "beliefs rooted in religion," and it "gives special protection to the exercise of religion." 81 The Supreme Court applied the Free Exercise Clause for the first time in Reynolds $v$. United States, where the issue was whether a Mormon could avoid penal sanctions provided by federal law for bigamy. The Court rejected this possibility with the view that to "permit this would be to make the professed doctrines of religious belief superior to the law of the land, and in effect to permit every citizen to become a law unto himself." ${ }^{82}$

In the middle of the last century, the Court's jurisprudential policy leaned toward obligating the states to observe a measure of tolerance toward religious

78. On religious individualism, see Robert N. Bellah et al., Habits of the Heart: Individualism and Commitment in American Life 232-35 (1985).

79. 50 U.S.C. app. $§ 456$ (j) (1958), amended by Pub. L. No. 90-40, § 1(7) (1967).

80. United States v. Seeger, 380 U.S. 163, 165-66 (1965).

81. Thomas v. Review Bd., 450 U.S. 707, 713 (1981).

82. Reynolds v. United States, 98 U.S. 145, 167 (1879). 
minorities. ${ }^{83}$ Without ever going as far as authorizing the most orthodox an exemption from observing laws that satisfy what courts call "compelling state interest" (what Europeans would consider as similar to laws of public order ${ }^{8+}$ ), the Court nevertheless took the opportunity in the 1960s to require the state to show proof that its public order laws satisfied a compelling state interest before claiming the power to impose them on the most religiously devoted of its citizens. The Court inaugurated this jurisprudence in Sherbert $v$. Verner, where it held that a Seventh-day Adventist could not be denied unemployment benefits because she refused to work on Saturday. ${ }^{85}$ The Court similarly held in Wisconsin v. Yoder that, contrary to the Wisconsin laws on compulsory schooling for children, the Amish could not be forced to send their children to school through age sixteen; the Free Exercise Clause gave them the right to remove their children before they reached this age, at the end of eight years of schooling, or at the age of fourteen. ${ }^{86}$ In similar cases, the Court applied a balancing test to see if the obligations imposed on the faithful in the exercise of their religion were justified by the overarching interest of public order. In light of this balancing test, if the state could not show that the statute in question responded to a compelling state interest, it had to grant the exemption solicited by the religious faithful.

In Employment Division, Department of Human Resources v. Smith, the Court decided to put an end to this jurisprudence. In this case, the question was whether Native Americans who smoked peyote as part of their ancestral religious rites could claim an exception to the laws of Oregon banning the usage of hallucinogens and receive unemployment benefits, where state law prohibited their distribution to persons fired for misconduct, including drug use. Reversing

83. This was notably the case when the Court refused states the right to mandate that school children salute the United States flag, requiring an exemption for those children belonging to the Jehovah's Witness religion, which believes that saluting a flag is tantamount to idol worship and therefore prohibited. W. Va. State Bd. of Educ. v. Barnette, 319 U.S. 624, 642 (1943), which reversed the much contested decision in Minersville Sch. Dist. v. Gobitis, 310 U.S. 586 (1940).

84. The Court refused to let religion serve as a pretext for bigamy, see Reynolds, 98 U.S. 145, for the avoidance of mandatory vaccinations, see Jacobson v. Massachusetts, 197 U.S. 11 (1905), for laws respecting Sunday as a weekly day of rest, see Braunfeld v. Brown, 366 U.S. 599 (1961), for the avoidance of military service, see Gillette v. United States, 401 U.S. 437 (1971) for the avoidance of tax payments, Hernandez v. Comm'r, 490 U.S. 680 (1989), for social contributions, see United States v. Lee, 455 U.S. 252 (1982), for refusing to register children with social security, see Bowen v. Roy, 476 U.S. 693 (1986), or even for pauses in highway construction, see Lyng v. Nw. Indian Cemetery Protective Ass'n, 485 U.S. 439 (1988).

85. See Sherbert v. Verner, 374 U.S. 398 (1963).

86. See Wisconsin v. Yoder, 406 U.S. 205 (1972). 
the Sherbert jurisprudence, the Court held: "IW|e cannot afford the luxury of deeming presumptively invalid, as applied to the religious objector, every regulation of conduct that does not protect an interest of the highest order." ${ }^{87}$ Furious, Congress enacted in 1993 the Religious Freedom Restoration Act, which required courts and tribunals to return to the Sherbert jurisprudence. In 1997, in City of Boerne v. Flores, ${ }^{88}$ the Court declared the Act unconstitutional, because it is not Congress, but the Supreme Court, who has the power to interpret the meaning of the Free Exercise Clause. In the case, the Court held that the archbishop of San Antonio could not avoid a city ordinance on the protection of historical landmarks on the pretext that the growth of his congregation of faithful required him to enlarge the church in Boerne.

Based on these events, it is clear that, as in the past, a law whose objective is to oppress, hinder, or discriminate directly against one or more religions is clearly unconstitutional as a violation of the Free Exercise Clause. On the other hand, a law which is in itself neutral from a religious point of view, and which imposes constraints or charges of a nature that contradict the Free Exercise Clause, or, in other words, discriminates against religion only indirectly, is no longer unconstitutional. That said, the states are free to grant religious exemptions from laws; and certain states authorize, for example, the consumption of peyote. The sense of the Smith jurisprudence, though, is that they are not obligated to do so. In theory, when the states grant these exceptions, they must not be contrary to the Constitution (for example, by the advantages they confer on religion in violation of the Establishment Clause) or contrary to federal law. ${ }^{89}$ In other words, religious interests do not come, or more accurately, no longer come systematically before public interest. Without a doubt, granting the exemptions can be seen as bestowing benevolent treatment on religions. But if this is the case, it will always be the effect of a policy choice (concretely, a law will be taken in this sense), not effectively a command in the name of the Free Exercise Clause. The Constitution does not obligate the state or its subdivisions either to grant these dispensations or religious exemptions from its laws, or to establish accommodations to facilitate religious exercise. ${ }^{90}$

87. Employment Div., Dep't of Human Res. v. Smith, 494 U.S. 872, 888 (1990).

88. City of Boerne v. Flores, 521 U.S. 507 (1997).

89. See Walz v. Tax Comm'n, 397 U.S. 664 (1970).

90. The point is particularly well explained by Justice Scalia. See City of Boeme, 521 U.S. at 541 (Scalia, J., concurring). 


\section{B. Reasonable Accommodation}

The Smith decision put an end to the presumption of unconstitutionality that, under the authority of the Sherbert jurisprudence, struck down state laws that involuntarily constrained the free exercise of religion. Devotees of a particular religion, therefore, no longer have the right to require state authorities to accord them dispensations that grant them wide latitude to practice their religion, if need be, notwithstanding the laws in force. On the other hand, these same devotees always have the right to require that the laws be not only written, but applied, in an absolutely neutral way. The least intimation that a text was written or is applied with the intention to harm a religion or to block it in its worship is fatal; the strict control of discriminations against religious action is, in truth, the strongest guarantee of religious freedom in the United States. If a judge no longer considers as true discrimination the indirect discrimination that can arise from the application of neutral laws of general applicability, nevertheless, he will not fail to subject the supposed laws to a meticulous examination. Since the Smith case, a religious devotee hampered in the exercise of his faith by current laws can no longer, as previously, partially impose an obligation of reasonable accommodation on public authority. On the other hand, he can obtain a reasonable accommodation from private authority, such as an employer.

Under the federal law of 1964, religious liberty can impose on private interests the obligation to accommodate the individual exercise of religious practice. Such is the case when the private interests at issue are those of an employer. The notion of reasonable accommodation, which the French would attribute to the legislation of Quebec, ${ }^{91}$ is in reality born of American employment law, and this

91. In its report, Commission de Reflexion, supra note 4, at paras. 1.2.3, 4.3.4.2, the Stasi Commission evokes two usages of the phrase "that the Quebecois characterize as reasonable accommodation" and "the principle that the Quebecois call reasonable accommodation." On the Quebecois regime, see José Woehrling, Droit Constitutionnel Étranger: L'actualité Constitutionnelle dans les Pays de Common Law et de Droit Mixte (Janvier-Juin 2002) Canada, Royaume-Uni [Foreign Constitutional Law: The Constitutional Reality in Common Law Countries and the Mixed Law of Canada and the United Kingdom] 53 Revue Française de Droit Constitutionnel [French Review of Constirutional Law] 187-96 (2003); and also, by the same author, see also José Woehrling, L'obligation d'Accommodement Raisonnable et l'Adaptation de la Société à la Diversité Religieuse [The Reasonable Accommodation Requirement and the Adaptation of Society to Religious Diversity] 43 McGill L.J. 325 (1998), which gives a complete and documented analysis of the consequences of 
context gives the notion its meaning. "Reasonable accommodation" was created in 1966 by the Equal Employment Opportunity Commission (EEOC), which is a federal agency charged with administering Title VII of the Civil Rights Act of 1964. Title VII forbids an employer "to fail or refuse to hire or to discharge any individual" because of religion. ${ }^{92}$ Without legislative precision, the reach of the employer's obligation to not discriminate on the basis of religion remains uncertain. Shortly after the statute came into effect, the EEOC, which is considered as having independent administrative authority to combat discrimination in the workplace, published guidelines for the statute's application. After 1966 and 1967, it was unlawful for an employer "to fail to reasonably accommodate the religious practices of an employee or prospective employee, unless the employer demonstrates that accommodation would result in undue hardship on the conduct of its business." ${ }^{93}$ In 1972, visibly satisfied, Congress modified the 1964 law by adding the reasonable accommodation standard. ${ }^{94}$

A great cacophony reigned among the inferior courts regarding how to interpret "reasonable accommodation" and "undue hardship." In 1977, in Trans-World Airlines Inc. v. Hardison, ${ }^{95}$ an employee who asked to not work on Saturday was told that it would be impossible to satisfy this request for two major reasons: first, because the trade unions refused to modify the seniority system which fixed personnel rotations for weekend work teams; second, the company refused to hire another employee to replace Hardison on Saturday because it would have to pay this employee increased wages to work on the weekend. The Supreme Court found in favor of the company. It reasoned that Title VII mandated that "similarly situated employees are not to be treated differently solely because they differ with

the O'Malley case, decided in 1985 by the Supreme Court of Canada. In this case, as Jose Woehrling explained, "Plaintiff Mrs. O'Malley, whose religion requires strict Sabbath observance, from sundown Friday until sundown Saturday, was allegedly the victim of indirect religious discrimination by her employer, who required her to work Friday night and Saturday. The Canadian Supreme Court held that the latter had failed to reasonably accommodate Mrs. O'Malley, either in modifying her work hours or in showing that such an arrangement would result in an undue burden for him." Id. at $330 \mathrm{n}$.5. It is clear that in this case, the court of Ontario was influenced by American law, particularly the Sherbert case of 1963, and by notions of reasonable accommodation and undue burden, created by the Equal Employment Opportunity Commission (EEOC) in 1966 and 1967. The words are the same, and the reasoning identical, proof that comparative constitutional law is operating.

92. 42 U.S.C. $\$ 2000 \mathrm{e}-2(\mathrm{a})(1)(2000)$.

93. EEOC Guidelines on Discrimination Because of Religion, 29 C.F.R. $\$ 1605.2($ b) (2004).

94. Equal Employment Opportunity Act of 1972, Pub. L. No. 92-261, 28 Stat. 103 (1972).

95. Trans World Airlines v. Hardison, 432 U.S. 63 (1977). 
respect to... religion," but it refused to read the law as obligating an employer to "deny the shift and job preference of some employees ... in order to accommodate or prefer the religious needs of others. ${ }^{.96}$ Considering the additional costs that Trans World Airlines would have had to incur in order to accommodate the religious needs of Hardison, the Court held that it was an "undue burden" to require an employer to "bear more than a de minimus cost."

In 1986, in its holding in Ansonia Board of Education v. Philbrook, ${ }^{98}$ the Court brought precision to the notion of reasonable accommodation. The case concerned an employee who, having exhausted three days paid leave provided by a collective-bargaining agreement, sought to obtain additional paid days off for religious observance. The Court considered that an offer of three days without pay, in addition to the three paid personal days provided by the collectivebargaining agreement, constituted a reasonable accommodation. Generally, the Court set aside the solution that lower courts had developed, which deemed that where many equally restricting solutions are possible, the employer has an obligation to choose the one the employee prefers. ${ }^{99}$

The rather strict interpretation of the notion of reasonable accommodation given by the Supreme Court agitated the religious lobbies influencing Congress. In 2003, the Senate proposed the Workplace Religious Freedom Act, which sought to obligate employers to satisfy the religious needs of their employees in a more systematic fashion. The notions of reasonable accommodation and, especially, undue hardship were redefined in light of the more radical and effective reach that was given another federal law that profoundly changed American society: the Americans with Disabilities Act of 1992. It is doubtful whether this bill works in terms of religion. The difficulties it raises are innumerable, the least of which is that each person, being able to choose his religion, would be free to require of his employer the most whimsical accommodations. ${ }^{100}$ Congress does not seem ready to give to the religious the same rights it gives to the disabled.

96. Id. at 71,81 .

97. Id. at $84-85$.

98. Ansonia Bd. of Educ. v. Philbrook, 479 U.S. 60 (1986).

99. Id. at $66-68$.

100. See James A. Sonne, The Perils of Universal Accommodation: The Workplace Religious Freedom Act of 2003 and the Affirmative Action of 147,096,000 Souls, 79 Notre Dame L. Rev. 1023, 1024 (2004) (describing an expectation of the possible requirements of the followers of the religion Serpent Handling Believers). 
When deployed against public authorities (schools, universities, and prisons), the notion of reasonable accommodation has even less reach than against the private sector. Because, in the public sphere, any accommodation risks conflict with the Establishment Clause, a definite rigidity in the application in this space of the principle of separation of church and state is inevitable. There does not exist, for example, a clause analogous to article 2 of the French law of 1905 , which provides for the possibility, not the obligation, to earmark public funds for chaplaincy services, intended to assure the free exercise of worship in public establishments such as schools, hospices, retirement homes, and prisons. That is not to say that these services do not exist; but if they exist, it is not so much because of a state obligation as for the protection of an individual right. The protection of the individual right varies depending on the public establishments under consideration. In prisons, the Supreme Court has held that prisoners retain their constitutional rights, in particular the right to practice their religion. Nevertheless the measures taken to guarantee the free exercise of religion for inmates are minimal. ${ }^{101}$

In the case of public schools, it is understood that the Establishment Clause creates opposition to what public authorities can do as far as introducing religion in public schools. On the other hand, public authorities do not have, as in France, the authority to proscribe what religion introduces into the school. The state's obligation of absolute neutrality, combined with the nature of "preferred liberty," assumes that freedom of expression would condemn, by hypothesis and by definition, a law like the French law of March 15, 2004, prohibiting conspicuous signs of religion in the public school. ${ }^{102}$

Not one of the American participants at this symposium could find a legal reason to justify it. How can this be explained? Simply by the fact that in the United States religious liberty cannot be disassociated from freedom of expression. Without a doubt the state cannot favor, encourage, or support religious expression in the school, but the state has to allow religious expression if it is the result of individual initiative, whether isolated or concerted. One student can,

101. See, e.g., O'Lone v. Estate of Shabazz, 482 U.S. 342 (1987); see also Cutter v. Wilkinson, 544 U.S. 709 (2005) (warning that prison security remained a compelling state interest when it comes to accommodating inmates' religious needs).

102. Law No. 2004-228 of March 15, 2004, Journal Officiel de la République Française [J.O.] [Official Gazette of France], March 17, 2004, at 5190, available at http://www.legifrance.gouv.fr/ WAspad/UnTexteDeJorf?numjo=MENX0400001 L. 
therefore, wear a religious symbol, as he would be able to wear any other expressive symbol, so long as he does not harm others; it is a personal choice. For example, a student could wear a black armband to protest the war in Vietnam. ${ }^{103}$ Similarly, in furtherance of the freedom of expression, students can choose to meet within the school to pray or meditate.

In 1981, in Widmar $v$. Vincent, ${ }^{10+}$ the Supreme Court held that where a university grants student associations access to certain areas it cannot discriminate by refusing access to those associations whose members want to pray, reflect, or discuss religious subjects. The Court reasoned that, in this case, the question is not whether allocating certain areas to student religious organizations is incompatible with the Establishment Clause, but rather whether from the moment the university "has opened its facilities for use by student groups... it can now exclude groups because of the content of their speech." 105 The response, as expected, was negative, and the Court explained: "We are not oblivious to the range of an open forum's likely effects. It is possible-perhaps even foreseeable-that religious groups will benefit from access to University facilities. ${ }^{106}$ In this sphere, freedom of expression takes precedence over the Establishment Clause.

We see by this that religious influence, indeed a certain proselytizing, is introduced into universities under the cover of freedom of expression. The Widmar decision greatly pleased Congress, always ready when the issue is religion, as the pressure of constituents and the extraordinary religiosity of society weighs on the elected. In 1984, Congress codified the Widmar decision in the Equal Access Act; even better, it extended the principle to secondary schools. When, in 1990, the law was challenged as unconstitutional for violating the Establishment Clause, the Court upheld the law. ${ }^{107}$ A little later, the Court decided that the principle of equal access was also applicable to elementary schools. ${ }^{108}$

After a long voyage, religious action is durably ingrained in schools because of the sacred character of freedom of expression. But is there not a risk that the

103. See Tinker v. Des Moines Indep. Cmty. Sch. Dist., 393 U.S. 503 (1969).

104. Widmar v. Vincent, 454 U.S. 263 (1981).

105. Id. at 273 .

106. Id.

107. Bd. of Educ. v. Mergens, 496 U.S. 226 (1990).

108. If school buildings are available for the use of certain organizations after school, a religious group offering films advocating Christian values must be allowed use of the building. See Lamb's Chapel v. Center Moriches Union Free Sch. Dist., 508 U.S. 384 (1993); see also Good News Club v. Milford Central Sch., 533 U.S. 98 (2001) (holding that the school must welcome a club for Christian children, ages 6-12). 
presence of religion in educational institutions unwittingly opens the door to increased religious influence? If religion is admitted to school in the hours after classes, is there not a fear that it could demand a presence during the school hours? This claim is already made, not for schools, but for universities. Recently the Court decided to hear the complaint of a student in the state of Washington who had received a scholarship from the state based on his school performance, but whose scholarship had been revoked based on a statute, itself adopted to support the state constitution, that said state money could not be used to pursue theological studies. ${ }^{109}$ Joshua Davey wished to study theology and become a priest. The question in this case was not whether the state was obligated under the Establishment Clause to refuse to provide public funds to seminaries, but rather if it could restrict that usage without violating the Free Exercise Clause. In other words, could the state, without violating the U.S. Constitution, inscribe in its own constitution that public funds can never finance religious instruction or religious worship? In a 7 to 2 decision, the Court responded in the affirmative. ${ }^{110}$ It considered that the funds at issue resulted in only a slight restriction on the free exercise doctrine. Without the measure of quasi-persecution at work in the aforementioned case involving the followers of the Santeria religion, ${ }^{11}$ the disbursement of the funds was only the expression of the will of the state not to lend its support to certain forms of education; nothing suggested that the law had been adopted in the spirit of animosity toward religion. The U.S. Constitution, therefore, places no positive obligation on the state to assure the effective exercise of the right to religious freedom. It forbids the state only from directly attacking this right. The Davey decision seems to indicate what course the Court will follow if religion, already present in the school sphere, requests entry into the curriculum.

\section{Conclusion}

The American separation of church and state is not the laïcité of France. Of that there is no doubt. The present series of essays allows us to better understand the difference. Laïcite is a term that can be understood in two ways. On one level, laïcité signifies the separation of church and state, or of religion and politics. On another level, laïcité, as it is more or less understood in France, recalls

109. Locke v. Davey, 540 U.S. 712 (2004).

110. See id. at 725.

111. Church of the Lukumi Babalu Aye v. City of Hialeah, 508 U.S. 520 (1993). 
the collection of civil, civic, and political values that come from the Declaration of the Rights of Man of 1789, the preamble to the Constitution of 1946, and the fundamental principles recognized by the laws of the Republic. These values form the moral conscience of the Republic and are the civil religion of the state. It is not in the first sense but in the second sense that the American conception of laïcité separates radically from the French conception.

Understood as the principle of the separation of church and state, laïcité operates in the United States in an infinitely harder and more rigid manner than in France. The American conception of the separation of church and state requires that the federal government be a federal state of neutrality without concessions, without privileges, and without amenities. State governments may have a little more leeway and take advantage of the necessary "room for play in the joints" 112 in striking a balance of their own between constitutional commands and states' freedoms. But, whatever policy they choose, all religions, all churches, and all sects, must be equally treated. None may be preferred, and each one must be left to its own devices to survive with respect to the laws. As opposed to the Catholic Church in France, no religion has ever been strong enough to receive financial assistance by the state in its educative mission. When, at the end of the $1960 \mathrm{~s}$, one seemed to be emerging, in Rhode Island or in Pennsylvania, as was the case in Lemon $v$. Kurtzman, ${ }^{113}$ the Court ruined these hopes in the name of the Establishment Clause.

As for religious freedom, it is not, as in France, aided, assisted, or even supported by public authority. Certainly, every effort is made so that religion is not hindered by either public or private sources, so that it remains free to practice. But no one has a constitutional right to a "reasonable accommodation" to freely practice his religion, and America is far from the efforts deployed in France, and in Europe generally, to satisfy religious worship and to respect religious practice.

If we are to summarize very briefly the differences between the two republics on this point, we could say this: Whereas in France, the minority religions, which if they are not oppressed are at least disadvantaged, try to rise to the level of the preferred religions, those in the United States have already lost all preference. This equality of status and treatment of all religions, churches, and sects is a mark of radical distinction between France and the United States. This nominal equality of all beliefs has many advantages. It allows the federal state and the

112. Walz v. Tax Comm'n, 397 U.S. 664, 669 (1970); see supra note 68 and accompanying text. 113. Lemon v. Kurtzman, 403 U.S. 602 (1971); see supra note 62 and accompanying text. 
federated states to practice, with respect to all religions, a policy of negative neutrality under a benign neglect attitude and no sense of guilt; it also enables them not to fear any religion, so much so that it encourages their multiplication. ${ }^{11+}$

The result of all of this is that religions can only truly prosper in the private sphere; and they prosper there more, especially because they are not recognized in the public sphere. In the United States, religion prospers in society, and it is often mobilized to serve those general interests that the state must not, cannot, and wants not to serve, in the name of the duty of neutrality that weighs on each of its acts.

Compared to the growing secularization of European society, severely judged and criticized on the other side of the Atlantic, ${ }^{115}$ the religiosity of American society is certainly that which most strikes the European spirit and, in particular, French scholarship. ${ }^{116}$ It is not at all certain that American society is as religious as the French think, and there exists in the United States a strong conservative current that says otherwise. American research itself is divided on the question. While certain lawyers see society as irretrievably struck by secularism as a result of Supreme Court jurisprudence, political scientists know well that in reality, religiosity is inscribed in the depth of American social tissue. ${ }^{117}$ The true question is how to explain it.

That said, if religion so profoundly permeates American sociéty, it is exactly because the state is completely separated from religion, because it does not interest itself in religion and is deprived by the Supreme Court of the possibility of

114. The Federalist No. 10 (James Madison), No. 15 (Alexander Hamilton) (explaining the advantages of having a multiplicity of religious factions and sects). Madison applied to political factions exactly the same remedies that the English had discovered to prevent the misdeeds of religious sects on society-he multiplied them. Voltaire (whose works Madison knew well) perfectly understood the advantageous consequences of this political imperialism: "If there were only one religion in England, despotism would be feared; if there were two, they would cut each other's throats; but there are thirty, they live in happy peace." Voltaire, Lettres Philosophiques (Sixième Lettre), in Mélanges XX (Jacques van den Heuvel ed., 1961).

115. See generally Brian C. Anderson, Secular Europe, Religious America, 155 Pub. Int. 143 (2004). 116. See Camille Froidevaux, Dieu et les Américains: La Fin d'une Exception? [God and the Americans: The End of an Exception?], 108 Le Débat [The Debate] 116 (2000); see also Camille Froidevaux, Le Puritain n'est pas Républicain |The Puritan is Not a Republican|, 1 Raisons PolITIQUEs 127 (2001); see also Fabienne Randaxhe, La Religion dans la Société Etats-Unienne: Une Affaire de Droit [Religion in American Society: A Case of Law], 14 LA Revue Tocqueville [The TocQueville Review] 33 (2003).

117. See generally Christopher L. Eisgruber, Secularization, Religiosity, and the United States Constitution, 13 Ind. J. Global Legal STud. 445 (2006) (analyzing religiosity in American society and the evolutions and causes over the course of the last century). 
taking an interest in it. In other words, it is the separation between church and state that every day creates and nourishes the religiosity of American society, as Tocqueville noted. ${ }^{118}$ He recommended that France adopt the same solution, a recommendation that was realized with the law of 1905 . But a century later, France, as secular as it is, has come to a completely different result than has the United States. French society is not as nearly filled with religiosity as American society. How can that be explained? In light of the American conception of the separation of church and state, one is tempted to say that it is because the state and religion are, in France, much less separated than one would like to say. It is not so much that in France the state provides more aid to churches than in the United States; but rather, in France, the Republic could not have asserted itself as the "polity" (association politique) ${ }^{119}$ of modern France without turning laïcité, notably at school, into a civil religion of which the United States never had need (insofar as no American ever dreamed of returning to the colonial epoch and to British domination).

The United States does not, therefore, have the second form of laïcité. It does not have a civil religion, and, to be accurate, the notion is the antipode of their culture. ${ }^{120}$ The state is neutral in the United States.

118. TocQueville, supra note 24 , at $340-47$.

119. The term "political association" recalls, of course, article 2 of the Declaration of the Rights of Man: "The goal of every political association is the conservation of the natural and inalienable rights of man." The Declaration of the Rights of Man and of the Citizen, supra note $8, \S 2$.

120. That is because the word laïcité, taken in its cultural, anthropological sense rather than simply its judicial sense, defies translation into English, as Carol Greenhouse as so well observed in her article. Carol Greenhouse, Separation of Church and State in the United States: Lost in Translation?, 13 Ind. J. Global Legal Stud. 493 (2006). 